\title{
Leaf proline accumulation and fruit yield of 'Pera' sweet orange trees under natural water stress
}

\author{
Luciana Marques de Carvalho1,* (D), Stela Braga de Araújo² (D), Hélio Wilson Lemos de Carvalho (iD), \\ Eduardo Augusto Girardi ${ }^{3}$ (D), Walter dos Santos Soares Filho ${ }^{3}$ (D) \\ 1. Empresa Brasileira de Pesquisa Agropecuária - Centro de Pesquisa Agropecuária dos Tabuleiros Costeiros - Aracaju (SE), Brazil. \\ 2. Universidade Federal de Sergipe - Centro de Ciências Exatas e Tecnologia - Departamento de Engenharia Química - São Cristovão (SE), Brazil. \\ 3. Empresa Brasileira de Pesquisa Agropecuária - Centro Nacional de Pesquisa de Mandioca e Fruticultura Tropical - Cruz das Almas (BA), Brazil. \\ Received: Mar. 11, 2020 | Accepted: Dec. 21, 2020 \\ Section Editor: Alberto Cargnelutti Filho \\ *Corresponding author: luciana.carvalho@embrapa.br \\ How to cite: Carvalho, L.M., Araújo, S.B., Carvalho, H.W.L., Girardi, E.A. and Soares Filho, W.S. (2021). Leaf proline accumulation and fruit yield \\ of 'Pera' sweet orange trees under natural water stress. Bragantia, 80, e1121. https://doi.org/10.1590/1678-4499.20200349
}

\begin{abstract}
The water deficit is one of the main limiting factors to the yield of sweet oranges. The present study aimed to determine alternative rootstocks to 'Rangpur' lime for 'Pera' sweet oranges grown on tropical hardsetting soils with greater potential tolerance to water deficit. Six citrus scion/rootstock combinations were grown during eight years in an orchard established in Sergipe, Brazil. The tree height, number of fruits per plant, cumulated fruit yield, leaf proline content and survival rate of trees were evaluated between $6^{\text {th }}$ and $8^{\text {th }}$ year after planting. Greater rate of tree loss occurred among the sweet orange onto 'Orlando' tangelo, which also induced the lowest cumulative fruit yield. After prolonged water deficit, moderate to high proline content was found in trees grafted on Sunki of Florida mandarin $\times$ C13 citrange $-012^{\circ}$ (TSKFL $\times$ CTC13-012), 'Orlando' tangelo, 'Indio' and 'Riverside' citrandarin. Conversely, after a short water deficit during the wet season, trees on 'San Diego' citrandarin and Rangpur lime clone of Centro Nacional de Pesquisa Mandioca e Fruticultura - CNPMF 03 'Rangpur' lime showed higher proline content. Trees onto TSKFL $\times$ CTC13-012 and 'Indio' also induced the greatest accumulated fruit yield at the $8^{\text {th }}$ year after planting. It is assumed that 'San Diego' and CNPMF 03 'Rangpur' induce response more quickly to water deficit, whereas TSKFL $\times$ CTC13-012 and 'Indio' are less susceptible to prolonged deficit. Therefore, trees on 'San Diego' and Indio citrandarin, CNPMF-03 'Rangpur' lime, TSKFL $\times$ CTC13-012 hybrid present greater potential to tolerate water deficit and produce more fruits on the hardsetting soils of the coastal tablelands of the Brazilian Northeast.
\end{abstract}

Key words: Citrus limonia, C. sunki, C. paradisi, drought tolerance, hardsetting soils, rainfed..

\section{INTRODUCTION}

Citrus is an important agricultural commodity in Brazil. Commercial sweet orange groves are spread over the Brazilian territory, although mostly concentrated in Southeast and Northeast regions. Those located on Northeast occur mainly in hardsetting soils of the coastal tablelands, where the presence of a cohesive layer on the top of B horizon prevents root deepening in dry periods and impairs the drainage in the wet season. Such soil characteristics combined with poor distribution and scarcity of rainfall, particularly in the dry season, aggravate the water deficit and contribute to the vulnerability to drought stress (Gomes et al. 2017). Most of them are in 1-10 ha areas, not irrigated, where smallholders usually carry out low-input management practices. Thus, the sweet orange (Citrus sinensis) trees often face water deficit in these areas, more intense and frequent during the dry summer.

With the commercial citrus species propagated by grafting, the scion tolerance to water deficit is much depending to rootstock. 'Rangpur' lime (Citrus limonia Osbeck) has been used as the main rootstock for sweet oranges, principally because of its moderate tolerance to the Citrus tristeza virus and water stress and, as well as high vigor in the nursery, 
high yield and fruit quality. However, the diversification of rootstocks has been suggested due to the recognition of the great vulnerability of orange orchards made up of a single scion/rootstock combination to abiotic and biotic stresses (Almeida and Passos 2011).

In citrus, numerous studies have reported the consequences of water deficit at both leaf and root levels (García-Sanchez et al. 2007; Gonçalves et al. 2016). Despite this, only a few studies were performed under natural water stress (Carr 2012). Among the mechanisms triggered by citrus trees to support the water stress are included stomatal closure and accumulation of solutes, such as the amino acid proline (García-Sanchez et al. 2007). The accumulation of this amino acid is one of the most common strategies of drought tolerant species (Szabados and Savoure 2010; Gonçalves et al. 2016). Zaher-Ara et al. (2016) suggested proline content could be used as a biochemical marker of water stress in citrus. The objective of this work was to determine alternative rootstocks to 'Rangpur' lime for 'Pera' sweet oranges grown on tropical hardsetting soils with greater potential tolerance to water deficit based in leaf proline content, fruit yield and survival rate.

\section{MATERIALS AND METHODS}

An experimental orchard was established in 2009 in an experimental area within the northeastern citrus producing polo, located in Umbaúba ( $11^{\circ} 22^{\prime} 37^{\prime \prime}$ S, 37 $40^{\prime} 26^{\prime \prime}$ W, 109 m), Sergipe, Brazil. With a typical hardsetting soil, this area has flat relief, frangipanis grayish clay, about $40 \mathrm{~cm}$ deep, and sandy clay texture, as described by Gomes et al. (2017). The climate is tropical rainy (hot and humid) type 'As', according to the Köppen classification, with maximum temperatures of $38.8^{\circ} \mathrm{C}$ and minimum temperature of $19.1^{\circ} \mathrm{C}$. Air-temperature data were provided by the meteorological station belonging to the National Institute of Meteorology and installed in Itabaianinha $20 \mathrm{~km}$ from the experimental site (Agritempo 2020). The lowest air-temperature mean was verified in the sixth year after planting $\left(19.1\right.$ to $\left.29.4{ }^{\circ} \mathrm{C}\right)$ and the highest in the seventh year $\left(21.1\right.$ to $38.8^{\circ} \mathrm{C}$; Fig. 1a). The rainfall volume was registered daily in the experimental area by a rain gauge.

Six rootstocks, CNPMF 03 'Rangpur' lime, 'Orlando' tangelo (Citrus paradisi Macfad. $\times$ Citrus tangerina hort. ex Tanaka), 'Indio,' 'Riverside' and 'San Diego' citrandarins [Citrus sunki (Hayata) hort. ex Tanaka $\times$ Poncirus trifoliata (L.) Raf.], and 'Sunki of Florida' (C. sunki) mandarin (TSKFL) $\times$ C13 citrange (C. sinensis $\times$ P. trifoliata) (CTC13) - 012 hybrid, were evaluated in combination with 'Pera CNPMF-D6' sweet orange, henceforth only 'Pera'. All commercial genotypes used are accessions of the active citrus germplasm bank of Embrapa Mandioca e Fruticultura and the hybrid TSKFL $\times$ CTC13 -012 was developed by the citrus breeding program of this institution. One-year-old trees were planted in August 2009 at $6 \times 3 \mathrm{~m}$ spacing (556 plants.ha ${ }^{-1}$ ) in a randomized block design with four replications and four plants per plot, managed without irrigation. Annually, all trees were fertilized according to recommendation for 'Pera' sweet oranges (Sobral et al. 2000). At the $6^{\text {th }}$ year after planting (YAP), some leaves were removed from trees to determine the leaf nutrient content (Table 1).

The total height (in meters) and the survival rate (percentage of alive trees) of the trees were determined on the $8^{\text {th }}$ YAP. The total number of harvested fruits per plant was registered from the $5^{\text {th }}$ to $8^{\text {th }}$ YAP and the cumulated fruit yield $\left(\mathrm{kg} \cdot \mathrm{ha}^{-1}\right)$ was determined on the $8^{\text {th }}$ YAP. The free leaf proline content was measured in the $6^{\mathrm{t}^{\text {th }}}, 7^{\text {th }}$ and $8^{\text {th }}$ YAP.

The proline content was determined in two fully-expanded leaves removed from the third node of branches of the middle third of trees without fruits. The leaves, immediately frozen at $-20^{\circ} \mathrm{C}$, had the content of proline extracted in the laboratory according to Bates et al. (1973). At the $6^{\text {th }}$ YAP, the samples for proline evaluations were collected in July, during a dry spell on the wet season, and at the $7^{\text {th }}$ and $8^{\text {th }}$ YAP were collected in February, during the dry season.

All data were submitted to ANOVA and the scion/rootstocks combinations were compared using Tukey's test when significant effects were detected by F-test $(\mathrm{p}<0.05)$. Moreover, root square transformations were done for all data that did not follow normal distribution. 
(a)

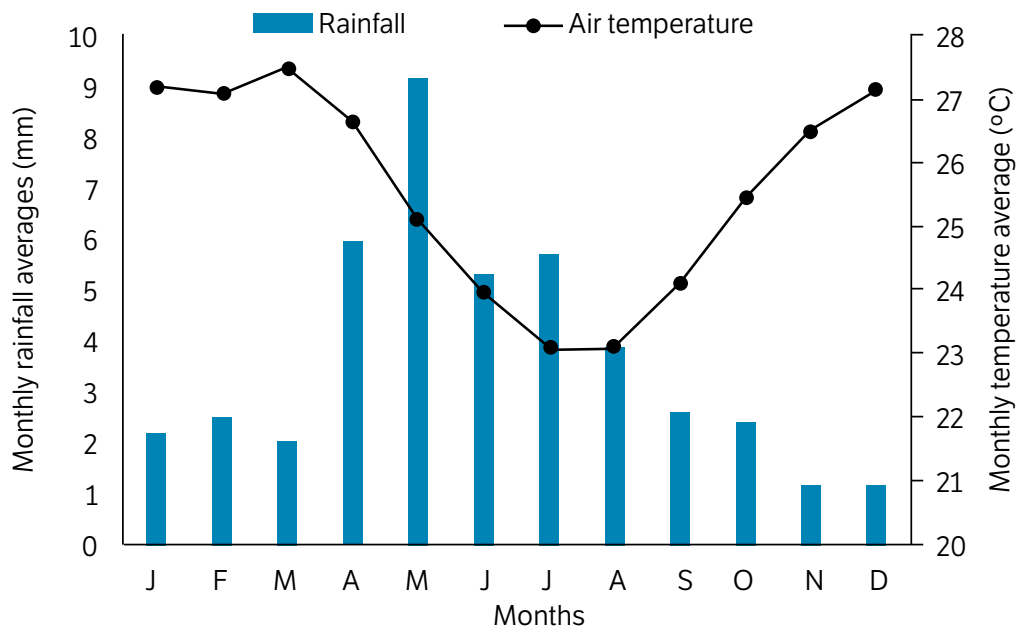

(b)

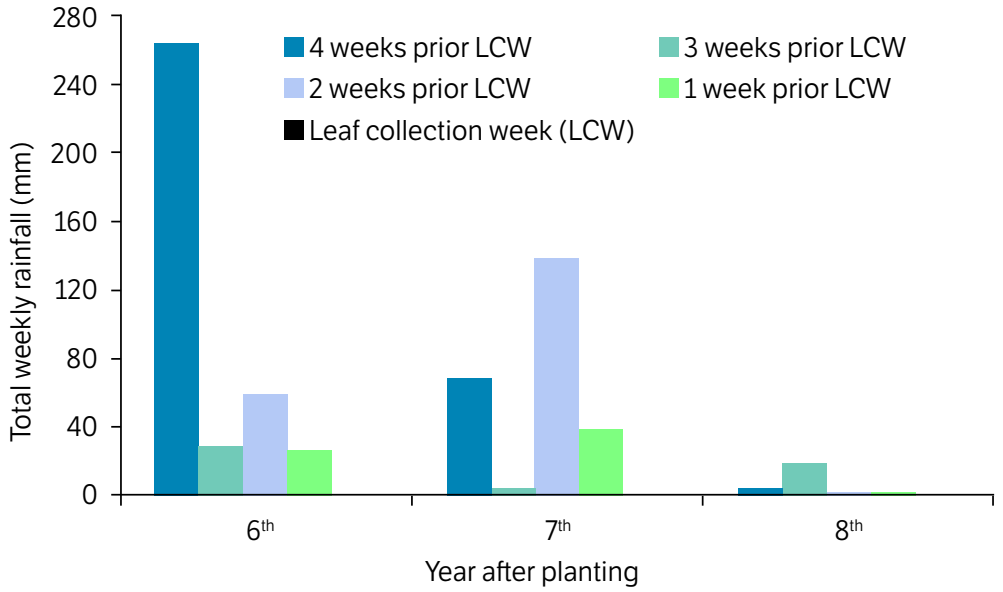

Figure 1. Monthly rainfall and mean air-temperature (a); rainfall volume on the sampling period for proline content and previous weeks (b) in 'Pera CNPMF-D6' sweet orange trees [Citrus sinensis (L.) Osbeck] grafted onto six citrus rootstocks grown in Umbaúba, Sergipe, Brazil.

Table 1. Leaf nutrient content, in $\mathrm{g} / \mathrm{kg}$, of leaves of 'Pera CNPMF-D6' sweet orange trees onto six rootstocks.

\begin{tabular}{ccccccccccc}
\hline \multirow{2}{*}{ Rootstock } & \multicolumn{9}{c}{${\text { Evaluated leaf } \text { nutrients }^{*}}^{*}$} \\
\cline { 2 - 12 } & $\mathbf{N}$ & $\mathbf{P}$ & $\mathbf{K}$ & $\mathbf{C a}$ & $\mathbf{M g}$ & $\mathbf{S}$ & $\mathbf{M n}$ & $\mathbf{Z n}$ & $\mathbf{C u}$ \\
\hline 'Rangpur' & 28.56 & 1.525 & 16.797 & 19.280 & 2.069 & 2.590 & 13.709 & 13.433 & 3.593 \\
\hline 'Indio' & 32.34 & 0.786 & 10.953 & 33.273 & 1.6 & 1.725 & 10.983 & 5.165 & 1.484 \\
\hline 'Riverside' & 28.88 & 0.798 & 9.915 & 32.401 & 2.949 & 1.662 & 12.679 & 5.182 & 1.654 \\
\hline 'San Diego' & 29.67 & 0.822 & 12.846 & 35.855 & 2.684 & 1.948 & 11.504 & 6.793 & 1.315 \\
\hline 'Orlando' & 27.52 & 0.861 & 13.038 & 37.855 & 2.767 & 2.095 & 11.395 & 3.616 & 1.205 \\
\hline $\begin{array}{c}\text { TSKFL } \times \\
\text { CTC13-012 }\end{array}$ & 29.36 & 1.107 & 6.957 & 28.925 & 2.849 & 2.901 & 17.202 & 18.407 & 4.054 \\
\hline
\end{tabular}

"all values were obtained by sampling in every tree of each scion/rootstock combination. 


\section{RESULTS AND DISCUSSION}

All scion-rootstock combinations presented leaf proline accumulation on the three evaluated periods (Table 2), including both dry and wet seasons (Fig. 1a). These findings are consistent with previous reports about water stress in citrus cultivars (Nolte et al. 1997; Kishor et al. 2005; Zaher-Ara et al. 2016; Arias-Sibillote et al. 2019). The presence of great amounts of proline in unstressed citrus trees occur when this amino acid accumulates far in excess of the demands of protein synthesis (Kishor et al. 2005). Beside it, the proline accumulation rises in response to water deficit (Nolte et al. 1997; Kishor et al. 2005; Campos et al. 2011; Girardi et al. 2017; Arias-Sibillote et al. 2019).

Table 2. Leaf proline content on the sixth $\left(6^{\text {th }}\right)$, seventh $\left(7^{\text {th }}\right)$, and eighth $\left(8^{\text {th }}\right)$ year after planting (YAP), tree height $(\mathrm{H})$ and survival rate $(\mathrm{SR})$ of 'Pera CNPMF-D6' sweet orange [Citrus sinensis (L.) Osbeck] associated to six rootstocks.

\begin{tabular}{|c|c|c|c|c|c|c|}
\hline \multirow{3}{*}{ Rootstock } & \multicolumn{4}{|c|}{ Proline content $\left(\mu \mathbf{g} \cdot \mathbf{g}^{-1}\right)$} & \multirow{3}{*}{$\begin{array}{c}\mathrm{H}(\mathrm{m}) \\
8^{\text {th }} \text { YAP }\end{array}$} & \multirow{3}{*}{$\begin{array}{l}\text { SR (\% } \\
8^{\text {th }} \text { YAF }\end{array}$} \\
\hline & \multirow{2}{*}{$\begin{array}{c}\text { Wet season } \\
6^{\text {th }} \text { YAP }\end{array}$} & \multicolumn{2}{|c|}{ Dry season } & \multirow{2}{*}{ Average } & & \\
\hline & & $7^{\text {th }}$ YAP & $8^{\text {th }}$ YAP & & & \\
\hline 'Rangpur' & 526.30Aa & $171.30 \mathrm{Ca}$ & $251.83 \mathrm{Bd}$ & $316.48 a$ & $2.30 a$ & 100 \\
\hline 'Indio' & $206.22 \mathrm{Bd}$ & $133.23 \mathrm{Cb}$ & $355.49 A b$ & $231.65 c$ & $2.37 a$ & 100 \\
\hline 'Riverside' & $283.09 \mathrm{Bb}$ & $90.47 \mathrm{Cc}$ & $359.86 \mathrm{Ab}$ & $244.48 c$ & $2.58 a$ & 100 \\
\hline 'San Diego' & $502.06 \mathrm{Aa}$ & $72.72 \mathrm{Cc}$ & 312.91Bc & $295.90 b$ & $2.32 a$ & 100 \\
\hline 'Orlando' & $189.51 \mathrm{Bd}$ & $62.40 \mathrm{Cc}$ & 461.17Aa & $237.69 c$ & $2.65 a$ & 83 \\
\hline TSKFL $\times$ CTC13 - 12 & 229.67Bc & $125.07 \mathrm{Cb}$ & 485.01Aa & $279.92 b$ & $2.65 a$ & 100 \\
\hline Average & $322.80 \mathrm{~B}$ & $109.20 \mathrm{C}$ & $377.71 \mathrm{~A}$ & 269.90 & & \\
\hline CV (\%) & & & & 6.73 & & \\
\hline
\end{tabular}

Within column, the values followed by the same lowercase letter do not differ significantly at $p \geq 0.05$, by the Tukey's test. For proline content, the values followed by the same uppercase letter in the lines do not differ significantly at $p \geq 0.05$ by the Tukey's test. CV $=$ coefficient of variation.

From the planting year to the $8^{\text {th }}$ YAP, there was many days without rain (Table 3). Since the 'Pera' trees were not irrigated and depended only on rainwater to satisfy their water requirement, they must have faced many episodes of natural water deficit across the years. With the lowest means of annual rainfall registered on the 3rd and 7th YAP, the highest mean airtemperature and number of days with temperatures over $30^{\circ} \mathrm{C}$ verified in the $7^{\text {th }}$ YAP (Table 3), more periods of water deficit seemed to occur particularly in the last one.

Table 3. Total and average rainfall, maximum and average temperature $(T)$ and number of days per year without rain, or with temperature (T) equal or above $30^{\circ} \mathrm{C}$ from the year of planting the sweet oranges $(0)$ to $8^{\text {th }}$ year after planting (YAP).

\begin{tabular}{|c|c|c|c|c|c|c|}
\hline \multirow{2}{*}{ YAP $^{1}$} & \multicolumn{2}{|c|}{ Annual rainfall $(\mathrm{mm})^{1}$} & \multicolumn{2}{|c|}{ Annual temperature $\left({ }^{\circ} \mathrm{C}\right)^{2}$} & \multicolumn{2}{|c|}{ Number of days/year } \\
\hline & Total & $8^{\text {th }}$ YAP & Mean & Maximum & No rain & $\mathrm{T} \geq 30^{\circ} \mathrm{C}$ \\
\hline 0 & $1,328.1$ & 110.7 & 26.1 & 35.2 & 220 & 222 \\
\hline 1 & $1,313.5$ & 109.5 & 26.2 & 35.2 & 201 & 197 \\
\hline 2 & $1,379.3$ & 114.9 & 25.2 & 36.3 & 203 & 152 \\
\hline 3 & 821.9 & 68.5 & 25.2 & 35.1 & 213 & 193 \\
\hline 4 & $1,736.3$ & 144.7 & 25.6 & 36.0 & 202 & 170 \\
\hline 5 & $1,440.3$ & 120.0 & 25.2 & 35.2 & 196 & 169 \\
\hline 6 & $1,237.1$ & 103.1 & 25.8 & 38.6 & 214 & 207 \\
\hline 7 & $1,001.2$ & 83.4 & 26.1 & 38.8 & 226 & 225 \\
\hline 8 & $1,176.1$ & 98.0 & 25.2 & 35.8 & 167 & 169 \\
\hline Average & $1,263.2$ & 105.3 & 25.6 & 36.24 & 202.75 & 189.3 \\
\hline
\end{tabular}

${ }^{1}$ Rainfall data obtained by a rain gauge installed in the experimental area. ${ }^{2}$ Temperature (T) data obtained in the weather station of National Institute of Meteorology (INMET) located $20 \mathrm{~km}$ from the experimental area. 
Much proline was accumulated even after short water stress (a dry spell), occurred during the wet season (May-August, Fig. 1a) of $6^{\text {th }}$ YAP (Fig. 1b), particularly in leaves from trees onto CNPMF 03 'Rangpur' lime (Table 2). Also, at average, leaves from trees on CNPMF 03 'Rangpur' lime presented the highest proline levels, followed by those on 'San Diego' citrandarin and TSKFL $\times$ CTC13-012 hybrid. In fact, the 'Rangpur' lime rootstock is widely recognized as tolerant to water deficit (Gonçalves et al. 2016; Girardi et al. 2017). However, the drought tolerance induced by it has been associated with its increased root hydraulic conductivity, root growth related to the remobilization of carbohydrate and relatively flexible cells wall, which contributes to appreciable water loss while maintaining positive turgor pressure under drought (Gonçalves et al. 2016).

The highest proline content (over $300 \mu \mathrm{g} \cdot \mathrm{g}^{-1}$ ) for most of the scion-rootstock combinations, excepting that onto CNPMF 03 'Rangpur' lime rootstock, was verified in the $8^{\text {th }}$ YAP (Table 2), when a more prolonged water deficit (Fig. 1b) may have occurred during the dry season (December-February, Fig. 1a). In this period, 'Pera' sweet oranges grafted on 'Orlando' tangelo and TSKFL $\times$ CTC13 - 012 were those that accumulated more proline. This superiority suggests these rootstocks would induce greater potential drought tolerance mainly under prolonged or more severe water stress. On the other hand, the more elevated investment in proline content might have contributed to the lower cumulated fruit yield (Table 4) in plants onto 'Orlando' tangelo.

Table 4. Means of total number of fruits per plant (NFP) at $6^{\text {th }}, 7^{\text {th }}$ and $8^{\text {th }}$ year after planting (YAP) and cumulated fruit yield of 'Pera CNPMF-D6' sweet oranges (Citrus sinensis L.) at 8th YAP onto six rootstocks

\begin{tabular}{|c|c|c|c|c|}
\hline \multirow{2}{*}{ Rootstocks } & \multicolumn{3}{|c|}{ NFP } & \multirow{2}{*}{$\begin{array}{c}\begin{array}{c}\text { Cumulated } \\
\text { yield }\left(\mathrm{t} \cdot \mathrm{ha}^{-1}\right.\end{array} \\
\mathbf{8}^{\text {th }} \text { YAP }\end{array}$} \\
\hline & $6^{\text {th }} Y A P$ & $7^{\text {th }}$ YAP & $8^{\text {th }} Y A P$ & \\
\hline 'Rangpur' & $153.1 \mathrm{a}$ & $405.5 a$ & $172.5 a$ & $93.82 \mathrm{c}$ \\
\hline TSKFL $\times$ CTC13 - 12 & $232.3 a$ & $335.5 a$ & $266.1 \mathrm{a}$ & $99.51 b$ \\
\hline 'Indio' & $185.1 \mathrm{a}$ & $341.5 a$ & $171.3 a$ & $107.53 a$ \\
\hline 'Riverside' & $202.1 a$ & $344.5 a$ & $75.5 b$ & $92.04 \mathrm{c}$ \\
\hline 'San Diego' & $163.2 a$ & $282.5 b$ & $246.1 a$ & $90.78 c$ \\
\hline 'Orlando' & $72.1 \mathrm{~b}$ & $247.5 b$ & $97.2 \mathrm{~b}$ & $62.52 d$ \\
\hline Average & 167.8 & 326.2 & 171.3 & 91.03 \\
\hline $\mathrm{CV}(\%)$ & & & & 6.77 \\
\hline
\end{tabular}

By contrast, surprisingly, it was verified relatively low contents of proline during the dry season of the $7^{\text {th }}$ YAP (Fig. 1b). It is important to highlight that heavy rain fell down in the few days prior to the proline sampling performed on the $7^{\text {th }}$ YAP (Fig. 1b), which may have provided rehydration. Campos et al. (2011) and Girardi et al. (2017) verified decreases on the proline contents of citrus trees submitted to water deficit followed by irrigation $24 \mathrm{~h}$ after deficit. Sharma and Verslues (2010) reported that stress-induced proline content is reversible, decreasing to basal levels when stress is no longer a limiting factor. After some rehydration, the proline content would be remobilized and degraded to release energy and nitrogen for the cell growth (Sharma and Verslues 2010; Kishor and Sreenivasulu 2014). According to Kishor and Sreenivasulu (2014), the nitrogen remobilization from protein and amino acid degradation predominates over soil absorption when nitrogen or moisture stocks are insufficient or unavailable in the soil. In this condition, more proline was found in CNPMF 03 'Rangpur' (Table 2).

Despite of the probable more frequent and prolonged water stress in the dry season of the $7^{\text {th }}$ YAP, all scion/rootstocks combination produced surprisingly greater number of fruits per tree in this year (Table 4). A similar result was reported by Gasque et al. (2016) for 'Navelina' sweet orange trees exposed to restriction on the water availability, followed by restarting the full irrigation. According to them, this fruit growth acceleration, known as compensatory fruit growth, is usual when irrigation at full dose restarts after a water restriction period. According to Shalhevet and Levy (1990) cited 
by Carr (2012), rain/irrigation after drought/water deficit induces flowering in tropics. Also, too much stress can result in production of too many flowers

At the end of the $8^{\text {th }}$ year after planting a loss of $17 \%$ of the trees grafted onto 'Orlando' tangelo was registered. However, the others did not differ in the number of alive trees in this year (Table 2). Also, lower cumulated fruit yield was found in trees grafted onto 'Orlando' tangelo in this year (Table 4). No reason was identified for the tree losses. Visual symptoms of incompatibility between the scion cultivar and this rootstock were not observed. Although difficult to determine the causes, the characteristic hardsetting soil from Coastal Tablelands are suggested as a possible cause of trees losses onto 'Orlando' tangelo citrus blight disease. According to Srivastava and Singh (2009), a clay gradient and compaction hardpan in subsurface are among the abiotic factors that favor citrus blight disease.

Despite reports of abnormal graft union of 'Pera' with Cleopatra mandarin (Moraes et al. 2011) and trifoliate hybrids (Carvalho et al. 2018), no visual incompatibility symptoms were found in any of the evaluated scion/rootstocks combinations. Rodrigues et al. (2019) also did not find symptoms in 'Pera' trees onto 'Indio' citrandarin and Schinor et al. (2013) verified typical symptoms of incompatibility only in 'Pera' trees grafted onto two of the 42 evaluated hybrids 'Sunki' mandarin $\times$ trifoliate. According to Pompeu Junior and Blumer (2019), however, the incompatibility is not always readily expressed, which implies the need for a greater number of seasons of observations to reach definitive conclusions.

The scion/rootstock combination did not differ at the $8^{\text {th }}$ YAP regarding the tree size, varying between 2.30 and $2.65 \mathrm{~m}$ (Table 2). Among the evaluated rootstocks in combination with 'Pera' sweet orange, both 'Indio' and TSKFL $\times$ CTC13-012 outperformed CNPMF 03 'Rangpur' on cumulated fruit yield (Table 4), whereas 'Riverside' and 'San Diego' citrandarins induced cumulated fruit yield similar to CNPMF 03 'Rangpur' lime. Therefore, TSKFL $\times$ CTC13-012 hybrid, 'Indio, 'Riverside' and 'San Diego' citrandarins may be good alternatives to the rootstock CNPMF 03 'Rangpur' lime regarding fruit yield.

The effects of natural water deficit on proline contents and fruit yield suggest that irrigation water saving techniques, such as the regulated deficit irrigation, might be an alternative strategy to face the driest years with less loss on the field. Ballester et al. (2014) suggested that citrus growers should consider the regulated deficit irrigation strategy as a promising alternative when long periods of shortage of water resources are expected. Thus, the most productive scion/ rootstocks combination in the environments subject to natural and frequent water deficit may be the best alternatives for new orchards.

\section{CONCLUSION}

It may be concluded that 'Indio' citrandarin followed by TSKFL $\times$ CTC13 - 012 hybrid favor higher cumulative fruit yield to 'Pera' sweet oranges. The TSKFL $\times$ CTC13 - 012 hybrid also induces greater tolerance to water deficit to those trees grown under natural water stress in this soil. The trees onto 'Indio' present intermediate levels of proline. 'San Diego' citrandarin, as well as CNPMF 03 'Rangpur' lime, respond faster than others to the frequent short water stress, which might favor high fruit yield in years without severe and prolonged water stress. Aiming the citrus diversification on tropical coastal tablelands, 'Indio' and 'San Diego' citrandarins, TSKFL $\times$ CTC13 - 012 hybrid and CNPMF-03 'Rangpur' lime could be good alternatives rootstocks for 'Pera' sweet oranges.

\section{AUTHORS' CONTRIBUTION}

Conceptualization: Carvalho, H. W. L. and Carvalho L. M.; Methodology: Carvalho L. M. and Carvalho H. W. L.; Investigation: Carvalho L. M. and Araújo S. B.; Writing - Original Draft: Carvalho L. M.; Writing - Review and Editing: Soares Filho, W. S. and Girardi, E. A.; Funding Acquisition: Soares Filho, W. S. and Girardi, E. A.; Resources: Soares Filho, W. S. and Girardi, E. A.; Supervision: Soares Filho, W. S and Carvalho, H. W. L. 


\section{DATA AVAILABILITY STATEMENT}

All dataset were generated or analyzed in the current study.

\section{FUNDING}

Empresa Brasileira de Pesquisa Agropecuária

https://doi.org/10.13039/501100003046

Grant No. 02.13.03.005.00.00

\section{ACKNOWLEDGMENTS}

Not applicable.

\section{REFERENCES}

AGRITEMPO: Sistema de Monitoramento Agrometeorológico. (2020). Pesquisa de dados meteorológicos para o estado de SE. [Accessed Feb. 5, 2020]. Available at: https://www.agritempo.gov.br/agritempo/jsp/PesquisaClima/index.jsp?siglaUF=SE\&lang=pt_br Almeida, C.O. and Passos, O.S. (2011). Citricultura brasileira: em busca de novos rumos - Desafios e oportunidades na região Nordeste. Cruz das Almas: Embrapa Mandioca e Fruticultura. [Accessed Feb. 11, 2020]. Available at: https://livimagens.sct.embrapa. br/amostras/00083440.pdf

Arias-Sibillotte, M., Borges, A., Díaz, P., Ferenczi, A. and Severino, V. (2019). Leaf proline content and its relation to fruit load and flowering in citrus under field conditions. Revista Brasileira de Fruticultura, 41, e-087. https://doi.org/10.1590/0100-29452019087

Ballester, C., Castel, J., El-Mageed, T.A.A., Castel, J.R., Intrigliolo, D.S. (2014). Long-term response of 'Clementina de Nules' citrus trees to summer regulated deficit irrigation. Agriculture Water Managenment, 138, 78-84. https://doi.org/10.1016/j.agwat.2014.03.003

Bates, L.S., Waldren, R.P. and Teare, I.D. (1973). Rapid determination of free proline for water stress studies. Plant and Soil, 39, $205-207$. https://doi.org/10.1007/BF00018060

Campos, M.K.F., Carvalho, K., Souza, F.S., Marur, C.J., Pereira, L.F.P., Bespalhok Filho, J.C. and Vieira, L.G.E. (2011). Drought tolerance and antioxidant enzymatic activity in transgenic ‘Swingle' citrumelo plants over accumulating proline. Environmental and Experimental Botany, 72, 242 250. https://doi.org/10.1016/j.envexpbot.2011.03.009

Carr, M.K.V. (2012). The water relations and irrigation Requirements of citrus (citrus spp.): a review. Experimental Agriculture, 48, 347377. https://doi.org/10.1017/S0014479712000038

Carvalho, W.S.G., Marinho, C.S., Arantes, M.B.S., Campbell, G., Amaral, B.D. and Cunha, M. (2018). Agronomic and Anatomical Indicators of Dwarfism and Graft Incompatibility in Citrus Plants. Journal of Agricultural Science, 10, 263-274. https://doi.org/10.5539/jas.v10n9p263

García-Sánchez, F., Syvertsen, J.P., Gimeno, V., Botía, P. and Perez-Perez, J.G. (2007). Responses to flooding and drought stress by two citrus rootstock seedlings with different water use efficiency. Physiologia Plantarum, 130, 532-542. https://doi.org/10.111 1/j.1399-3054.2007.00925.

Gasque, M., Martí, P., Granero, B. and González-Altozano, P. (2016). Effects of long-term summer deficit irrigation on 'Navelina' citrus trees. Agricultural Water Management, 169, 140-147. https://doi.org/10.1016/j.agwat.2016.02.028 
Girardi, E.A., Cerqueira, T.S., Cantuarias-Avilés, T.E., Silva, S.R., Stuchi, E.S. (2017). Sunki mandarin and Swingle citrumelo as rootstocks for rain-fed cultivation of late-season sweet orange selections in northern São Paulo state, Brazil. Bragantia, 76, 501-511. https://doi. org/10.1590/1678-4499.2016.350

Gomes, J.B.V., Araújo Filho, J.C., Vidal-Torrado, P., Cooper, M., Silva, E. and Curi, N. (2017). Cemented Horizons and Hardpans in the Coastal Tablelands of Northeastern Brazil. Revista Brasileira de Ciência de Solo, 41, e0150453. https://doi.org/10.1590/18069657rbcs20150453

Gonçalves, L.P., Alves, T.F.O., Martins, C.P.S., Souza, A.O., Santos, I.C., Pirovani, C.P., Almeida, A.-A.F., Coelho Filho, M.A., Gesteira, A.S., Soares Filho, W.S., Girardi, E.A. and Costa, M.G.C. (2016). Rootstock-induced physiological and biochemical mechanisms of drought tolerance in sweet orange. Acta Physiologiae Plantarum, 38, 174. https://doi.org/10.1007/s11738-016-2198-3

Kishor, P.B.K. and Sreenivasulu, N. (2014). Is proline accumulation per se correlated with stress tolerance or is proline homeostasis a more critical issue? Plant, Cell \& Environment, 37, 300-311. https://doi.org/10.1111/pce.12157

Kishor, P.B.K., Sangam, S., Amrutha, R.N., Laxmi, P.S., Naidu, K.R., Rao, K.R.S.S., Rao S., Reddy, K.J., Theriappan, P. and Sreenivasulu, N. (2005). Regulation of proline biosynthesis, degradation, uptake and transport in higher plants: Its implications in plant growth and abiotic stress tolerance. Current Science, 88, 424-438.

Moraes, L.A.C., Moreira, A. and Pereira, J.C.R. (2011). Incompatibility of 'Cleopatra' mandarin rootstock for grafting citrus in Central Amazon, State of Amazonas, Brazil. Revista de Ciências Agrárias, 54, 299-306. https://doi.org/10.4322/rca.2012.026

Nolte, K.D., Hanson, A.D. and Gage, D.A. (1997). Proline Accumulation and Methylation to Proline Betaine in Citrus: Implications for Genetic Engineering of Stress Resistance. Journal of the American Society of Horticultural Science, 122, 8-13. https://doi.org/10.21273/ JASHS.122.1.8

Pompeu Junior, J. and Blumer, S. (2019). Comportamento de porta-enxertos em área afetada pela morte súbita dos citros. Citrus Research \& Technology, 40, e1048. https://doi.org/10.4322/crt.18319

Rodrigues, M.J.S., Araújo Neto, S.E.A., Andrade Neto, R.C., Soares Filho, W.S., Girardi, E.A., Lessa, L.S., Almeida, U.O. and Araújo, J.M. (2019). Agronomic performance of the 'Pera' orange grafted onto nine rootstocks under the conditions of Rio Branco, Acre, Brazil. Revista Brasileira de Ciências Agrárias, 14, e6642. https://doi.org/10.5039/agraria.v14i4a6642

Schinor, E.H., Cristofani-Yaly, M., Bastianel, M. and Machado, M.A. (2013). Sunki Mandarin vs Poncirus trifoliata Hybrids as Rootstocks for Pera Sweet Orange. Journal of Agricultural Science, 5, 190-200. https://doi.org/10.5539/jas.v5n6p190

Sharma, S. and Verslues, P.E. (2010). Mechanisms independent of abscisic acid (ABA) or proline feedback have a predominant role in transcriptional regulation of proline metabolism during low water potential and stress recovery. Plant, Cell \& Environment, 33, 18381851. https://doi.org/10.1111/j.1365-3040.2010.02188.x

Sobral, L.F., Souza, L.F.S., Magalhães, A.F.J., Silva, J.U.B. and Leal, M.L.S. (2000). Resposta da Laranjeira-Pêra à Adubação com Nitrogênio, Fósforo e Potássio em um Latossolo Amarelo dos Tabuleiros Costeiros. Pesquisa Agropecuária Brasileira, 35, 307-312. https://doi. org/10.1590/S0100-204X2000000200009

Srivastava, A.K. and Singh, S. (2009). Citrus Decline: Soil Fertility and Plant Nutrition. Journal of Plant Nutrition, 32, 197-245. https://doi. org/10.1080/01904160802592706

Szabados, L. and Savouré, A. (2010). Proline: a multifunctional amino acid. Trends in Plant Science, 15, 89-97. https://doi.org/10.1016/j. tplants.2009.11.009

Zaher-Ara, T., Boroomand, N. and Sadat-Hosseini, M. (2016). Physiological and morphological response to drought stress in seedlings of ten citrus. Trees, 30, 985-993. https://doi.org/10.1007/s00468-016-1372-y 